\title{
Response of some metabolic activities of wheat plants to different treatments of marine macroalgae from the Red Sea, Egypt
}

\author{
Mohamed Talaat ${ }^{1}{ }^{*}$, Abel Kareem S.H. Mohamed ${ }^{1}$, Mohamed Z. \\ Nassar $^{2}$, Nageh F. Abo-Dahab ${ }^{1}$

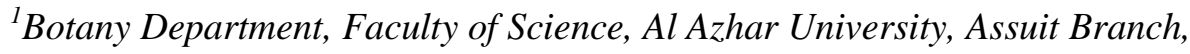 \\ Egypt \\ ${ }^{2}$ National Institute of Oceanography and Fisheries, Suez Branch, Egypt.
}

\begin{abstract}
:
In the present study, some experiments were conducted using wheat plants (Triticum aestivum L.) to study the effect of different seaweed treatments on some biochemical changes in the plants. Five different species of seaweed treatments were applied, namely; Halimeda opuntia, Caulerpa racemosa, Cystoseira myrica, Saragasum aquifolium, and Actinotrichia fragilis. The results showed that the wheat plant treated with different seaweeds increased the activity of peroxidase enzymes at the vegetative stage of plant growth. The highest peroxidase activity was observed in the leaf plant treated with Halimeda opuntia. Whereas, catalase activity was increased in the strain leaves with all applied treatments, with a maximum increase with Halimeda opuntia, Saragasum aquifolium, and Actinotrichia fragilis. Further results showed that the level of total carbohydrates and other metabolic activities such as proline and malondialdehyde (MAD) content were raised after all treatments, in particular after the application of the species; Sargassum aquifolium, Actinotrichia fragilis, and Caulerpa racemosa. However, the highest increase in MAD content was recorded in the leaves treated with Halimeda opuntia. Thus; the application of some macroalgae on wheat plants influenced nutrient transformation and soil properties, leading to improved wheat growth, yield, and development.
\end{abstract}

Keywords Marine macroalgae, antioxidant enzymes, carbohydrates, prolines, wheat plants.

\section{Introduction}

Marine macroalgae, or seaweed, are aquatic plants that belong to the plant kingdom of Thallophyta. Brown algae (Phaeophyceae), red algae (Rhodophyceae), and green algae (Chlorophyceae) may all be classified according to their pigmentation. Among these marine macroalgae, brown seaweed is used as a bio-fertilizer in agriculture (Bakrudeen et al., 2017). Interestingly, biofertilizers play a vital role in maintaining soil fertility and essential components 
that are needed for organic farming. These organic fertilizers provide several minerals and nutrients in the soil required to improve plant growth and crop yield production (Rouphael et al., 2018). Recently, seaweed has been replaced in agriculture to enhance plant growth because it acts as a bio-stimulant and biofertilizer (Hashem et al., 2019). Treatment with seaweed biomass increases nutrient uptake of soil and makes it resistant to environmental stress. In many countries, including France, Spain, Vietnam, Thailand, Indonesia, Bangladesh, Malaysia, Philippines, Japan, China, and Korea, mass cultivation of seaweed is common (García-Poza et al., 2020).

Moreover, seaweed and seaweed-derived compounds have been widely used as amendments in crop production due to the presence of a number of plant growth-regulating compounds, carbohydrates, vitamins, and minerals that help to maintain soil fertility, while other macronutrients and micronutrients promote faster seed germination and an increase in yield (Mirparsa et al., 2016). Many recent researches have revealed that these marine macroalgae may be used as biofertilizers to increase plant growth and production (Hashem et al., 2019). However, Khan et al. (2009) reported that the metabolic activity of many seaweed products has not been fully exploited due to the lack of scientific information on the growth factors present in seaweed and their mode of action in affecting plant growth. Although seaweed fertilizer in liquid form has gained importance in enhancing crop yield (Salah El Din et al., 2008), there is little data on soil conditioning and crop productivity through seaweed application in granular/powder form. Algae extract foliar application was indicated in several researches to improve the growth characteristics of various crop species (Latique et al., 2013). It was reported that the application of different successive extracts of Asparogopsis taxiformis thallus powder to the soil, as a biofertilizer, gave a significant increase in the growth of Vicia faba (El-Barody et al., 2007). Previously, the application of an extract from algae to soil or foliage increased the ash, protein, and carbohydrate content of potatoes. However, some of the red algae species, i.e. Laurencia obtusa, Corallina elongate, and Jania rubens, are effective fertilizers for maize growth and sugar content (Safinaz and Ragaa, 2013).

The wheat plant (Triticum aestivum L.) is one of the important cereal crops in Egypt. It plays an essential role and is used as the basic food requirement 
of the human population. This is the major crop that is being utilized for food and is cultivated in the larger areas of Egypt. According to Muhammad et al. (2013), adding various seaweeds to the soil improved all of the soil's physico-chemical and biological characteristics, as well as the crop production. They also found that the wheat crop morphological and agronomical parameters increased positively when plants were treated with different seaweeds. Thus, seaweeds play an important role in enhancing plant defense against pests and diseases that cause problems for some plant species (Cluz et al., 2004), reducing salt stress (Mancuso et al., 2006), drought stress (Zhang and Ervin, 2004), and heat stress (Zhang and Ervin, 2008). In addition, enriching pea plants with 10 to $15 \%$ algae extract increased production and improved seed quality when compared to the negative control (Nawar and Ibrahim, 2014). There is not enough information available about the application of seaweed to the growth and yield of wheat plants. Safinaz and Ragaa (2013) stated that the application of an algae mixture to the soil increased the dry weight, plant phosphorus, and nitrogen content of maize (Zea mays L.) plants.

When plants are exposed to environmental stress, reactive oxygen species (ROS) are produced. These activated oxygen damages protein, membrane lipid, and nucleic acid cellular constituents (Xie et al., 2019). Plant cells accumulate various compounds, such as antioxidants and secondary metabolites, as an adaptive response to stress conditions (Kosar et al., 2015). A number of enzymatic antioxidants (Catalase and peroxidase) are produced in plants due to abiotic stresses that protect plants against ROS-produced oxidative agents (Nazi et al., 2016). The positive effects of seaweed on the plant growth criteria of various plant species may be due to the presence of plant growth-promoting substances/hormones in these marine algae (Thorsen et al., 2010). The benefit of seaweed as a source of organic matter and fertilizer nutrients has led to its use as a soil conditioner for centuries (Nabti et al., 2017). Moreover, the studies of Kumar and Sahoo (2011) and Mohy El-Din (2015) demonstrated that seaweed could serve as an alternative biofertilizer as it is ecofriendly, cheaper, and delivers substantial economic and environmental benefits to farmers.

Regarding the effects of marine macroalgae on the germination and early growth stages of plants, wheat genotypes is an effort to improve production potential for farmers and provide knowledge of suitable tolerant cultivars for 
constrained soil. The goal of this study was to assess strategies for maximizing the benefits of applying marine macroalgae (seaweeds) to wheat genotypes.

\section{Materials and Methods}

\section{Marine macroalgae (seaweeds) and cultivar conditions}

Five marine macroalgae (Halimeda opuntia, Caulerpa racemosa, Cystoseira myrica, Saragasum aquifolium, and Actinotrichia fragilis) were seasonally collected from summer 2017 to spring 2018 from two different sites. These sites represent different hydrographic habitats along the north western coast of the Red Sea. The sample collection was performed using snorkeling at the two sites. The first site was the shore in front of the National Institute of Oceanography and Fisheries, Hurghada Branch, while the second site was a mangrove forest $15 \mathrm{~km}$ south of Safaga City. Seaweeds are dried and ground to a fine powder. About $30 \mathrm{~g}$ of the dried powder was mixed with the experimental soil before plants were cultivated. The investigated marine algae were identified by Aleem (1978), Coppejans and Beeckman (1990). After that, wheat grains were surface sterilized for 3 minutes with $1 \%$ sodium hypochlorite and then rinsed three times with sterile distilled water. The first group was grown under the above seaweed and the second group was untreated, which was used as a control (plants without algal treatment).

\section{Growth conditions and plant cultivation:}

The experimental plant used in the present investigation was Triticum aestivum L (Gemiza 11, Gemiza 171 and Misr 2, which are represented by S1, S2 and S3, respectively). The grains of the plant were obtained from the center of Agriculture, Assiut University. The plant was grown in the normal clay soil of $4000 \mathrm{~g}$ per plastic pot $(30 \mathrm{~cm}$ in diameter $)$ in a greenhouse under natural conditions at the Faculty of Science, Al Azhar University, Assiut, Egypt. All pots were seeded with ten grains per pot and three pots were used for each treatment. The pots were irrigated with tap water every 6 days until the fourth leaf appeared. The pots were irrigated with tap water to $60-70 \%$ of their water-holding capacity (WHC) just after growing. The experiment was set up in a fully random manner, 
with pots being randomized every two days and three replications. The experiment was carried out in the open air under natural conditions with $26 \pm 2{ }^{\circ} \mathrm{C}$ at day and $18 \pm 2{ }^{\circ} \mathrm{C}$ at night. After plants were harvested, for dry weight measurements, the plant samples were cleaned with distilled water, divided into shoots and roots, weighed, and oven-dried at $80^{\circ} \mathrm{C}$ for 24 hours. The plant's leaf length, fresh weight, and dry weight were all measured.

\section{Determination of photosynthetic pigments}

At harvesting, the photosynthetic pigments (chlorophyll $a, b$ and carotenoids) were measured using the spectrophotometric method as recommended by Lichtenthaler, 1987.

\section{Determination of total carbohydrates}

The Anthrone-sulphuric acid method (Fales, 1951 and Schlegel, 1956) was used for the determination of carbohydrates. A calibration curve using pure glucose was made and the data expressed as mg glucose/g DW.

\section{Determination of proline and lipid peroxidation contents}

According to Bates et al. (1973), proline content was measured. The proline concentration was determined using a calibration curve for proline and expressed as mg/gm DW. Malondialdehyde (MDA) formation was measured using the thiobarbituric acid reaction as described by Madhava and Sresty (2000) to determine lipid peroxidation (MDA). The concentration of MDA was calculated by using an extinction coefficient $(155 \mathrm{mM})$ and the results were expressed as $\mu \mathrm{g} \mathrm{MDA} / \mathrm{gm}$ FW.

\section{Determination of plant antioxidant enzyme activities}

\section{a. Catalase activity measurement:}

The activity of catalase was determined by Aebi (1984). Add $3 \mathrm{ml}$ of the reaction solution $\left(50 \mathrm{mM}\right.$, of phosphate buffer, $\mathrm{pH} 7.0$, and $30 \% \mathrm{~W} / \mathrm{V}_{2} \mathrm{O}_{2}$ ) to $0.5 \mathrm{ml}$ of enzyme extract. The activity of catalase was estimated by the decrease 
in absorbance at $240 \mathrm{~nm}$ as a consequence of $\mathrm{H}_{2} \mathrm{O}_{2}$ consummation (Havir and Mellate, 1987).

\section{b. Determination of peroxidase activity:}

The peroxidase activity was determined following Anjum et al. (2011) with slight modifications. The assay medium consisted of $2.5 \mathrm{~mL}$ of $100 \mathrm{mM} \mathrm{K}$ phosphate buffer ( $\mathrm{pH} 5.5), 100 \mu \mathrm{L}$ of $1 \mathrm{mM}$ guaiacol, and $0.1 \mathrm{~mL}$ of enzyme extract. The reaction was started by the addition of $300 \mathrm{~mL}$ of $1.3 \mathrm{mM} \mathrm{H}_{2} \mathrm{O}_{2}$ to oxidize guaiacol and produce a dark brown product. The increase in absorbance at $470 \mathrm{~nm}$ was recorded using a spectrophotometer.

\section{Statistical analysis:}

Using the SPSS 20.0 software program, the data was subjected to oneway ANOVA. Three replicate values were used to calculate the mean. Duncan's multiple range tests were used to compare means, and statistical significance was determined at the $5 \%$ level.

\section{Results}

\section{Effect of seaweed application on the growth rate of a wheat plant}

As a general trend; the seaweed application influenced wheat (Triticum aestivum L.) genotypes to varied degrees, while the control plant showed normal shoot growth. Under Halimeda opuntia, Saragasum aquifolium, and Actinotrichia fragilis; the plants treated with these seaweeds showed a reasonably high improvement in growth rate (Fig. 1). When the wheat plant Misr 2 was treated with all marine algae, the leaf length was the longest, as seen in Fig 1.While Halimeda opuntia improved the shoot length of the wheat genotypes Gemiza 11 and Gemiza 171 by about $51.3 \mathrm{~cm}$ plant $^{-1}$, Gemiza 11 and Gemiza 171 had the same effect on the leaf length as Actinotrichia fragilis, Saragasum aquifolium, and Caulerpa racemosa, with 44.00 and $48.60 \mathrm{~cm}^{-1 a n t}{ }^{-1}$, respectively (Fig. 1) as the control. 
Changes in the fresh and dry weights of Triticum aestivum shoots as a result of different treatments with marine algae are presented in Tables 1 and 2. In wheat genotypes Gemiza 11, Gemiza 171, and Misr 2, the highest shoot fresh weight was found in the plants irrigated with $H$. opuntia by about $54.41,56.84$, and $58.74 \mathrm{~g} \mathrm{pot}^{-1}$, respectively. The shoot's fresh weight, on the other hand, was lowest in all wheat genotypes (Gemiza 11, Gemiza 171, and Misr 2) with only $37.63,23.81$, and 36.70 gpot $^{-1}$, respectively, when treated by C. racemosa application as shown in Table1. In regards to shoot dry weight, a significant difference $(\mathrm{P} \leq 0.5)$ among the treatments was found. The highest shoot dry weight was found in the plant treated with $H$. opuntia and S. aquifolium, followed by the plant treated with A. fragilis, whilst, the lowest value was recorded in the plant irrigated with $C$. racemosa as compared to the control sample as shown in Table 2.

\section{Carbohydrate content in the wheat genotypes under algal application:}

When seaweed was applied to the plant growth, it caused significantly increased in carbohydrate content in all tested wheat genotypes (Fig. 2). All selected species showed an increase in the content of total carbohydrates in the genotype Misr 2 as compared to other wheat plants Gemiza 11 and Gemiza 171.

The maximum increase in total carbohydrate content was observed in the genotype Misr 2 when the plant is grown under S. aquifolium (350 mg. $\left.\mathrm{g}^{-1} \mathrm{DW}\right)$ compared to untreated. Compared to control, A. fragilis caused a significant increase in total carbohydrate content in all wheat genotypes Gemiza 11, Gemiza 171, and Misr 2 with 340, 310, and $250 \mathrm{mg} \mathrm{g}^{-1} \mathrm{DW}$, respectively. When the plant was used to grow $H$. opuntia and $S$. aquifolium, however, genotype Gemiza 11 had lower carbohydrate content, ranging from $160 \mathrm{mg} \mathrm{g}^{-1} \mathrm{DW}$ to $230 \mathrm{mg} \mathrm{g}^{-1} \mathrm{DW}$. 


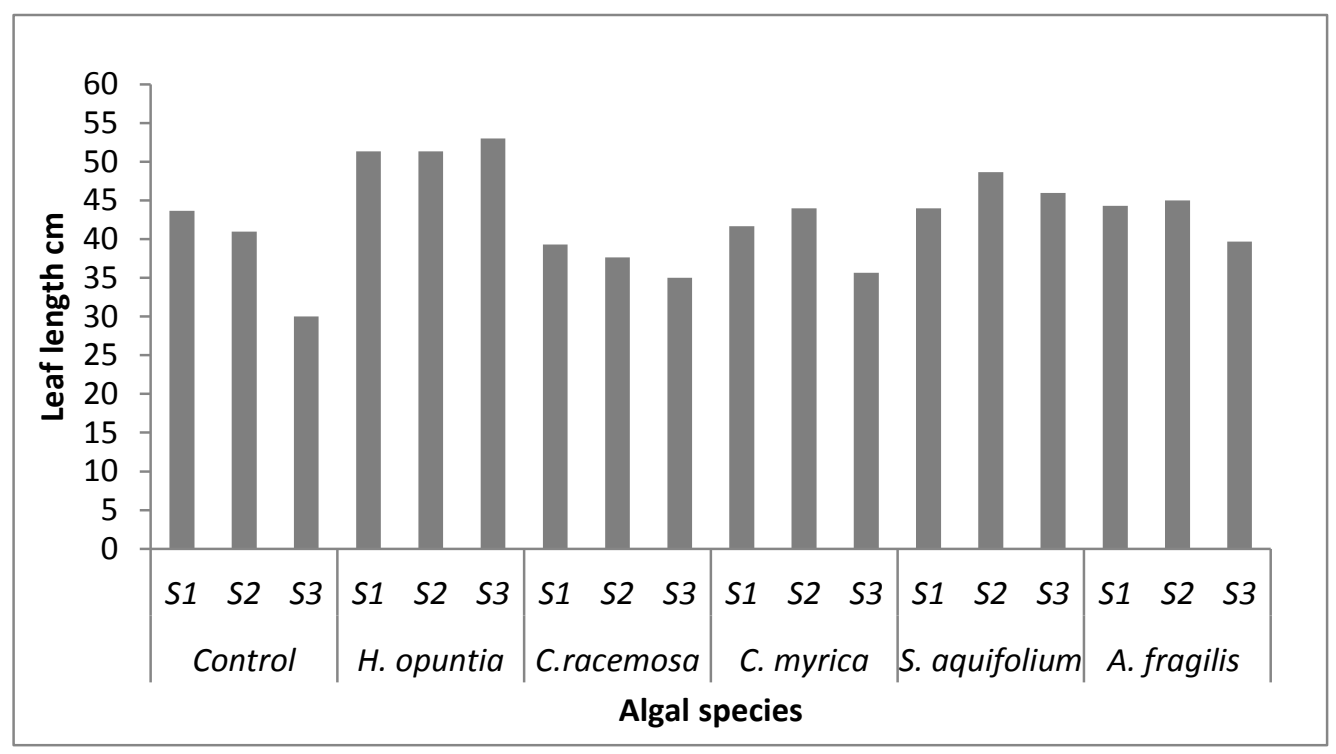

Fig. 1: Leaf length of various wheat genotypes that grown with some marine algae which are collected from some coasts of the Red Sea. Data are means of three replicates $\pm \mathrm{SE}(\mathrm{S} 1=$ Gemiza 11, S2= Gemiza 171 and S3 = Misr 2).

Table 1: Shoot fresh weight of wheat plants cultivated with some marine algae which were collected from some coasts of the Red Sea.

\begin{tabular}{lllllll}
\hline \multirow{2}{*}{ Treatment } & \multicolumn{2}{l}{ Shoot fresh weight of wheat plants $\left(\mathrm{g} \mathrm{pot}^{-1}\right)$} \\
\cline { 2 - 6 } & Gemiza 11 & $\%$ & Gemiza 171 & $\%$ & Misr 2 & $\%$ \\
\hline Control & $49.38 \pm 1.80$ & 100 & $46.11 \pm 1.38$ & 100.00 & $40.71 \pm 0.81$ & 100.00 \\
\hline H. opuntia & $54.41 \pm 1.54$ & 110.19 & $56.84 \pm 1.70$ & 123.28 & $58.74 \pm 1.03$ & 144.26 \\
\hline C. racemosa & $37.63 \pm 4.67$ & 67.20 & $23.81 \pm 2.61$ & 51.65 & $36.70 \pm 1.45$ & 90.13 \\
\hline C. myrica & $41.74 \pm 3.09$ & 84.53 & $44.93 \pm 1.34$ & 97.45 & $44.73 \pm 0.82$ & 109.86 \\
\hline S. aquifolium & $51.49 \pm 2.09$ & 104.27 & $42.64 \pm 0.73$ & 92.47 & $52.67 \pm 1.77$ & 129.36 \\
\hline A. fragilis & $50.38 \pm 3.54$ & 102.02 & $51.52 \pm 5.47$ & 111.74 & $44.92 \pm 5.79$ & 110.32 \\
\hline LSD=0.05 & $=12.9734870268$ & & $=9.61257195634$ & & $=10.9458695024$ \\
\hline
\end{tabular}


Table 2: Shoot dry weight of wheat plants cultivated with some marine macroalgae which were collected from some coasts of the Red Sea.

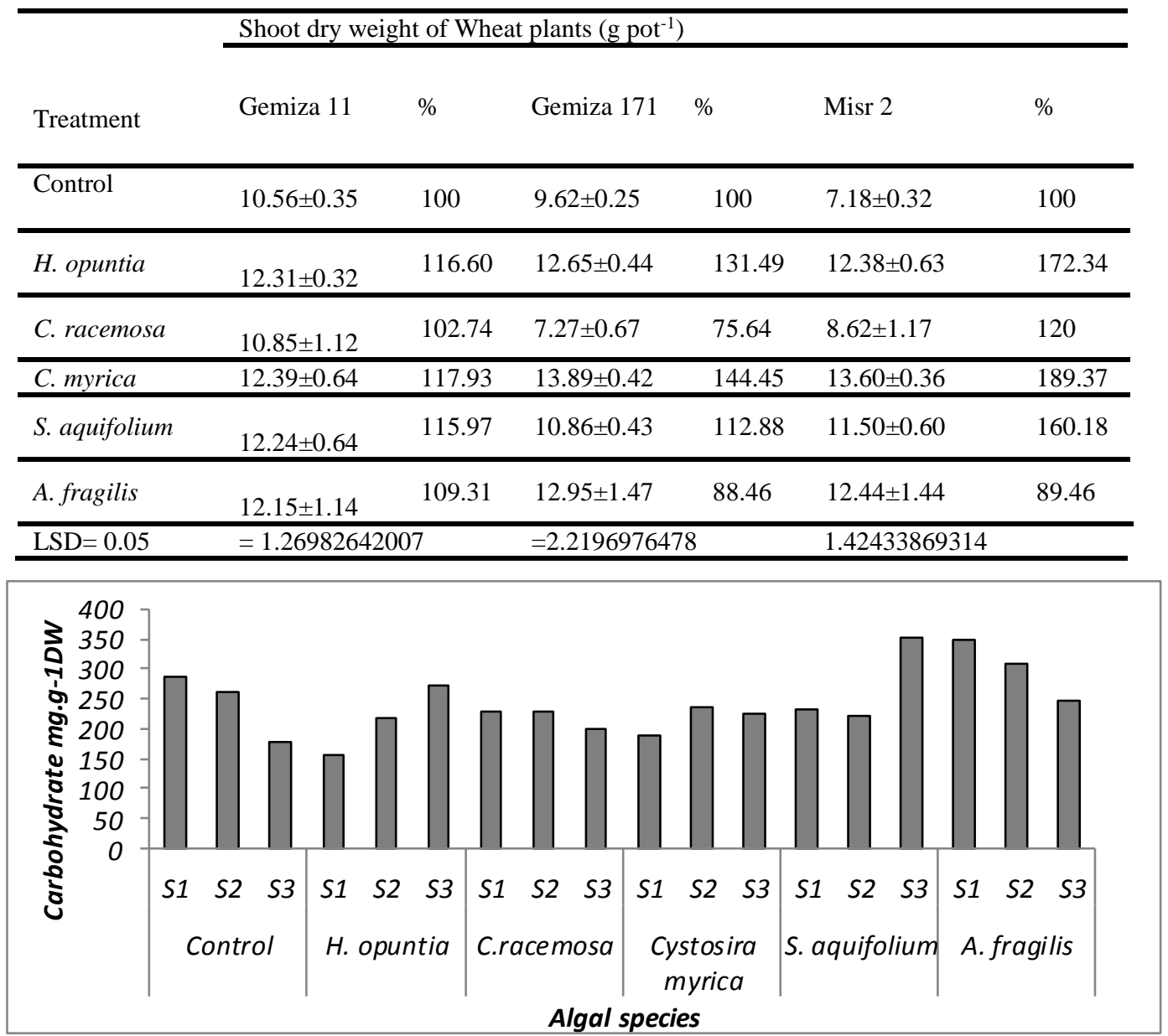

Fig. 2: Carbohydrate contents of various wheat genotypes that treated with some seaweeds. Data are means of three replicates \pm SE. Significant differences $(\mathrm{P} \leq$ $5 \%)$ between treatments and genotypes are indicated by different letters $(\mathrm{S} 1=$ Gemiza 11, S2= Gemiza 171 and S3 = Misr 2). 
Similar to control treatments, there was no discernible difference in the content of total carbohydrates in the genotype Gemiza 171when the plant was treated with seaweed (macro marine algae). Based on these results, the application of selected seaweeds increased the content of total carbohydrates in the leaf cells of wheat genotypes, which led to the improvement of plant growth and yield production (Fig. 2).

\section{Proline and MDA content}

It was obvious from Fig. 3a that the addition of C. racemosa to the wheat plant led to a great increase in the shoot proline content of all wheat plant genotypes (11, 7 and $5 \mathrm{mg} / \mathrm{g}$ fresh wt. in Gemiza171, Misr 2 and Gemiza 11, respectively), followed by the plant watered and treated by A. fragilis $(6 \mathrm{mg} / \mathrm{g}$ fresh wt. in Gemiza171 and Misr 2) with respect to the control $(4.5 \mathrm{mg} / \mathrm{g}$ fresh While, the lowest proline content was found in the shoots of all wheat plants treated with $H$. opuntia, followed by Gemiza 11 and Misr 2 when plants were treated with A. fragilis and S. aquifolium, respectively; as shown in Fig.3a.

In comparison to other macroalgae; only $C$. myrica showed no significant effect on the shoot proline content as compared to the control in all plant species. The changes in lipid peroxidase are represented as MDA accumulation in plant cells when plants grow under environmental stress. Similarly, MDA content in the wheat genotypes Gemiza171 and Gemiza 11was increased when the plant was treated with $S$. aquifolium followed by the wheat genotype Gemiza171 under the macro marine algae $C$. racemosa as compared to the control sample.

As mentioned in the results of proline content, application of marine algae also decreased MDA content in all tested wheat genotypes. However, H. opuntia showed the lowest MDA content of all wheat plants compared to other ones. Also, in the same trend as proline content, the seaweeds A. fragilis and C. myrica showed no significant effect on the MDA accumulation in the wheat genotypes Gemiza 171, Misr 2, as shown in Fig. 3b. Based on these results, the decrease in proline content in the leaf plant of wheat genotype under seaweed helps in the increase in plasma membrane stability of plant cells by making osmo-protectant. 

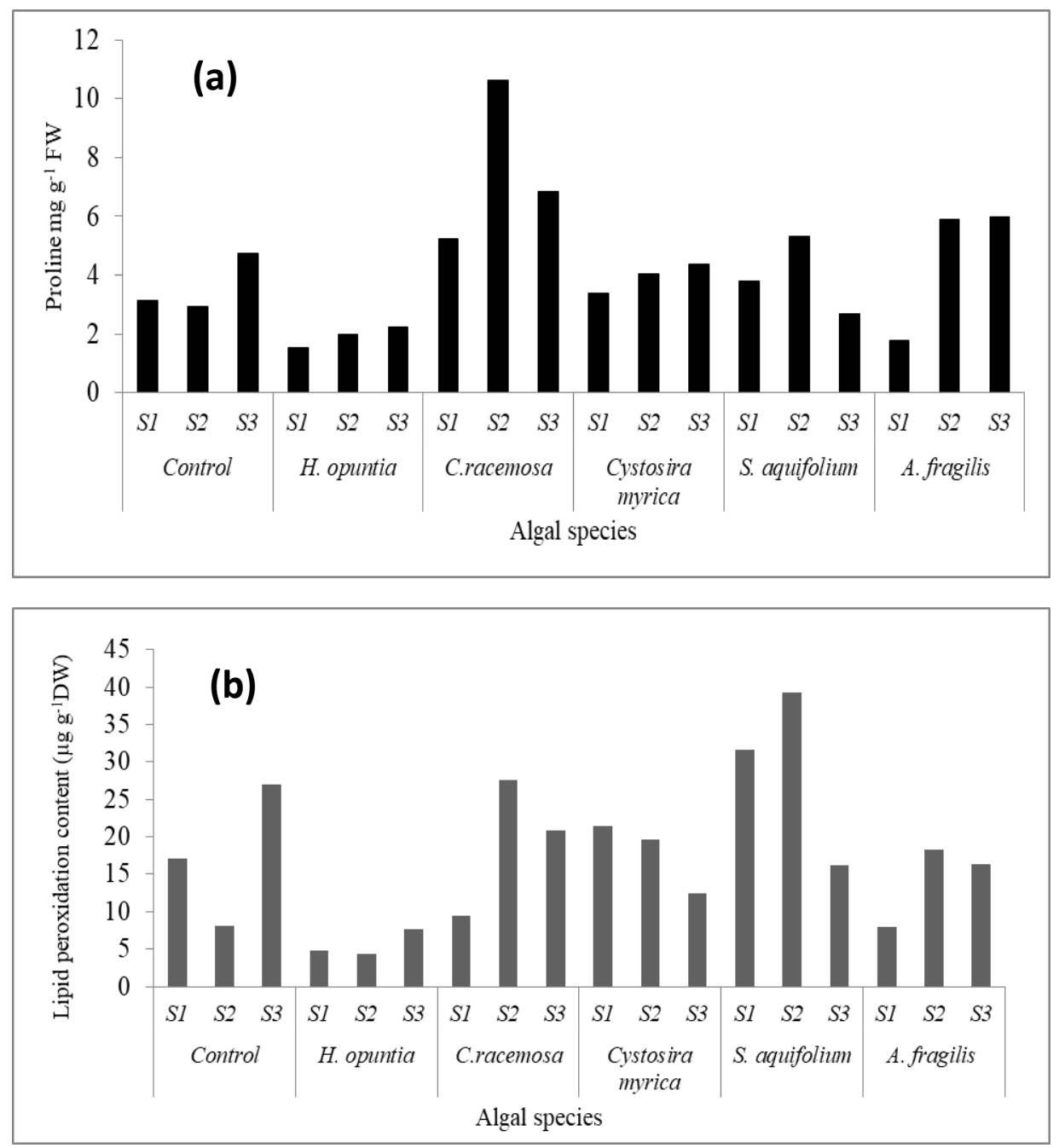

Fig. 3a, b: Proline contents (3a) and lipid peroxidation contents (MAD) (3b) of various wheat genotypes that treated with some seaweeds. Data are means of three replicates \pm SE. Significant differences $(\mathrm{P} \leq 5 \%)$ between treatments and genotypes are indicated by different letters $(\mathrm{S} 1=$ Gemiza $11, \mathrm{~S} 2=$ Gemiza 171 and S3 = Misr 2). 


\section{Catalase and peroxidase antioxidant enzymes}

The activity of catalase (CAT) and peroxidase (POD) of wheat genotypes is presented in Fig. 4a, b. The results showed that catalase activity was significantly enhanced by the application of seaweed as a bio-fertilizer on wheat plant species. However, the genotypes Gemiza 11 and Misr 2 showed lower catalase activity when plant-treated with all seaweeds compared to the genotype Gemiza171; it was significantly greater significant increase in the activity of the catalase antioxidant enzyme of the wheat plant under all seaweed application. As shown in Fig. 4a, the marine algae $C$. myrica and $C$. racemosa increased the catalase activity in Gemiza171 (0.9 unit $\mathrm{mg}^{-1} \mathrm{FW}$ ) in comparison to Misr 2, which showed the lowest catalase antioxidant activity $\left(0.4\right.$ unit mg $\left.^{-1} \mathrm{FW}\right)$ that was grown under S. aquifolium. Among the genotypes, Gemiza171 doesn't differ in the activity of the antioxidant catalase enzyme when plants are treated with $H$. opuntia and S. aquifolium as compared to control. However, treatment of wheat genotypes with seaweed increased POD activity slightly, as shown in Fig.4b. In contrast to the control plants, the application of plants with seaweed resulted in a significant decrease in peroxidase activity. However, the lowest reduction was reported in the genotypes Gemiza171 and Misr 2 in comparison to Gemiza11 which had higher POD activity under C. myrica, S. aquifolium, and A. fragilis as compared to control (Fig. 4b).

\section{Discussion}

The aim of this study was to compare the relative changes in shoot growth of three wheat genotypes under-treated and untreated irrigated-plants and to access the possible efficiency of seaweeds for use as a biofertilizer.

The seaweed fertilizers could help the soil to create an environment suitable for root growth by increasing microbial diversity, resulting in improved soil content and water holding capacity (Abbott et al., 2018). Also, the application of marine algae improves biological activities like respiration and nitrogen mobilization, and mineralization of mineral nutrients (DePascale et al., 2017). 

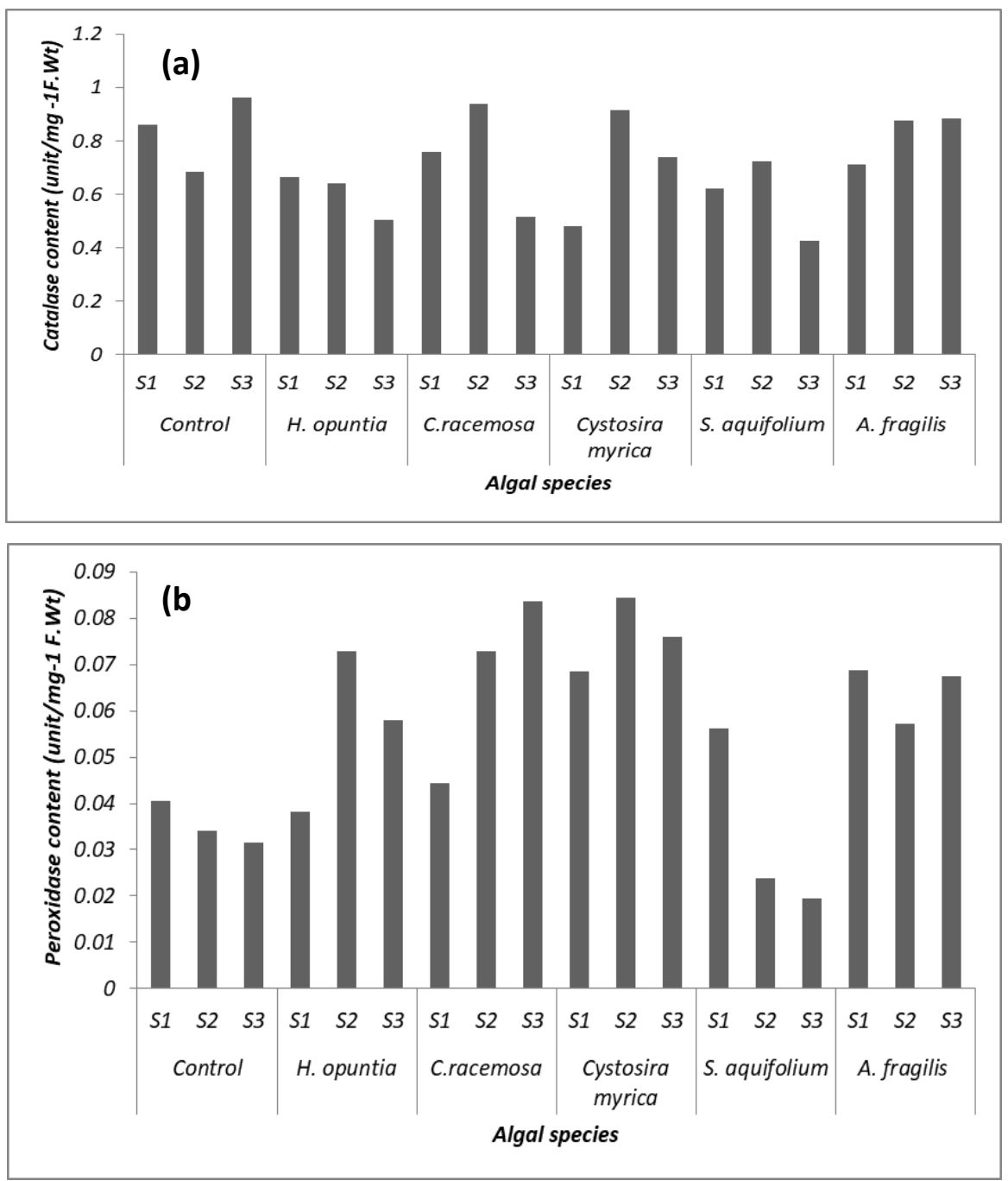

Fig. 4a, b: Catalase enzymes (CAT) (4a) and peroxidase enzymes (POD) (4b) of various wheat genotypes that treated with some marine algae. Data are means of three replicates \pm SE. Significant differences $(\mathrm{P} \leq 5 \%)$ between treatments and genotypes are indicated by different letters $(\mathrm{S} 1=$ Gemiza $11, \mathrm{~S} 2=$ Gemiza 171 and S3 = Misr 2). 
Even so; $H$. opuntia can be used to improve the physicochemical properties of soil, which in turn increases plant growth and productivity. Seaweeds are a rich source of polysaccharides that may affect soil aggregation directly or indirectly after their decomposition by soil microorganisms (Heltan $\boldsymbol{e t}$ al., 2015). Also, Davari et al. (2012) reported that organic matter contained in seaweed biofertilizer is known to stimulate the growth rate of some plant species due to its nutrient content. The application of seaweed as a biofertilizer in sufficient quantities increased the level of soil nutrients, minerals necessary for plant growth and stimulated the growth rate of field crops (Mirparsa et al., 2016). The presence of some growth regulators, macro and micronutrients, may be responsible for the positive increase in plant growth and division (Tarakhovskaya et al., 2007).

The most effective seaweed treatment in this study was Halimeda opuntia, which caused the greatest stimulation in wheat growth under normal conditions. The presence of a higher level of total carbohydrates and proline content in $H$. opuntia could explain the observed benefit over the other used seaweeds. The distinctive effect of $S$. aquifolium, on the other hand, could be attributed to its significantly higher carbohydrate content than the other seaweeds studied. Because of their high content of polysaccharides and plant growth regulators with a wide range of biological content, most marine microalgae are considered valuable resources for plant improvement (Hamed et al., 2018 and Ganesan et al., 2019). Our findings were similar to the recent investigation by Hashem et al. (2019). They hypothesized that the stimulatory effect of seaweed on growth and productivity was due to its constituents, which included a wide range of growth-promoting hormones, total carbohydrates, and phenolic compounds.

Leaf growth can possibly be induced due to the high uptake of water and minerals from the soil after being treated with marine macro-algae. In the present study, leaf length was significantly increased by the treatment with seaweeds; $H$. opuntia, S. aquifolium, and A. fragilis with wheat varieties compared to $C$. racemosa and $C$. myrica. In comparison to the Gmazia 11 genotype, wheat plants such as Misr 2 and Gmizia171 had a significant increase in leaf length. This result could be attributed to the presence of some hormonal compounds in marine macro-algal granular, such as auxins and gibberellins, which mitigate the negative 
effects of environmental conditions on wheat growth (Nassar et al., 2016) and help recover plants after damage (EI Shoubaky and Salem, 2016). The current result was in agreement with those of Tuhy et al. (2015). They suggested that the application of different seaweeds led to an increase in plant biomass, which is due to the presence of a high amount of mineral fertilizer.

Similarly, wheat plants treated with seaweed exhibited an increase in fresh and dry weights, which indicates that the components in seaweed had a considerable effect on shoot development. The highest values were found for plants treated with $H$. opuntia, S. aquifolium, and A. fragilis. While the lower values were observed when the plants were applied by $C$. racemosa and $C$. myrica. The presence of some growth-promoting substances could explain the increase in growth parameters (MohyEl-Din, 2015) or due to nutrient content (Kalaivanan et al., 2012). Our results coincided with those of earlier studies on Vigna sinensis (Sivasankari et al., 2006), Vigna mungo (Kalaivanan et al., 2012), Zea mays (Al-Shakankeryet al., 2014), and wheat plants (Kumar and Sahoo, 2011, Kumar et al. 2012, and MohyEl-Din, 2015). They concluded that the application of seaweed to pea plants significantly increased the vegetative growth characteristics such as leaf length and total fresh and dry weight. Our findings revealed that $H$. opuntia, S. aquifolium, and A. fragilis had the highest maximum values in this regard, with no statistically significant difference between them. The phytohormone content of the algal application may be responsible for the enhanced effect on wheat plant growth characteristics (Yakhin et al., 2017). Algal granules, which play an important role in cell division and expansion. As a result, shoot growth and plant fresh and dry weight increased, as suggested by (Chiaiese et al., 2018).

\section{Carbohydrate contents}

The results of the present study indicated an increase in the total carbohydrates of the plant irrigated with untreated and treated algae. This is due to the absence of some minerals in untreated algae that alter carbohydrate accumulation and distribution in wheat plants. The results were in agreement with Ganesan et al. (2019), who reported increased carbohydrate content in some crop species irrigated with seaweed than in untreated ones. In contrast, the decreases in the total content of carbohydrates of the tomato shoot and root of the irrigated 
plant with marine algae were detected in the work done by EL-Sheikh $\boldsymbol{e t}$ al . (2020).

It was reported that the application of seaweed has a significant positive effect on wheat yield and its carbohydrate content. Our results confirm the data of Hashem et al. (2019), who claimed that the effect of seaweed on plants is a favorable condition that promotes plant growth (in all growth parameters) and total carbohydrate content, resulting in higher crop yields. Macroalgae treatments such as $H$. opuntia and $S$. aquifolium tended to stimulate a positive effect on wheat yield. An increase in carbohydrate levels in treated seaweed plants is a common indicator of antioxidant parameters; this has been linked to plant growth stimulation and a high level of the antioxidant enzyme (Pise \& Sabale, 2010). Wheat plants are protected from the negative effects of declining carbohydrate content by adding $H$. opuntia and $S$. aquifolium to the soil. Under normal conditions, the observed enhancement effect of algal treatments on carbohydrates indicated that these treatments maintained a higher carbohydrate content than the control. Similar results were recorded by Rathore $\boldsymbol{e t}$ al. (2009), who discovered that SLF-treated soybean plants had higher carbohydrate levels than untreated controls. Korzen et al. (2015) discovered that the plant growth substances in SLF boost the carbohydrate content of plant leaves. Total carbohydrate accumulation was found to be slightly higher in all wheat genotypes used in this study than in the control. Meanwhile, when compared to untreated wheat plants (Misr 2), seaweed-treated wheat plants (Misr 2) had significantly higher total carbohydrates.

This finding is consistent with the observed increase in proline content in response to seaweed treatments, which occurred in the same order. This means that seaweed increased total carbohydrates by stimulating proline biosynthesis, which helps plants grow and produce more carbohydrates. The same outcomes were obtained by Korzen $\boldsymbol{e t}$ al. (2015) for Ulva rigida and Pramanick $\boldsymbol{e t}$ al. (2017) for Potato tubers. Increased amounts of carbohydrates, which are known to play an important role in osmoregulation and also improve plant growth in a way similar to hormones, may be attributed to the growth-enhancing potential of seaweeds like $H$. opuntia and S. aquifolium. 


\section{Proline content, lipid peroxidase level (MAD)}

Decreased levels of some metal ions are known to affect the permeability of membranes, which may lead to water stress conditions inducing the production of proline (Basak et al., 2001). Proline content is proved to be essential for stress tolerance because of its active role in osmotic adjustment, protection of the enzyme structure, stabilization of membranes, and defense against hydroxyl radicals (Silva-Ortega et al., 2008). According to the obtained data, proline content and lipid peroxidase level (MAD) reached their maximum effect when plants were treated with seaweed. In comparison to the control, proline levels were higher in seaweed-treated plant wheat leaves. Furthermore, when plants were treated with marine algae, higher levels of proline were accumulated. Proline may protect plant cells from harmful oxidative stresses by reducing the harm caused by reactive oxygen species (ROS) as a result of various defense mechanisms, according to (El Rabey et al., 2016). As a result, the increased proline content of wheat plants treated with $C$. racemosa compared to control and other treated plants suggests that proline is one of the wheat plant's defense mechanisms against oxidative problems caused by environmental conditions. Proline content can use osmotic adjustment to stabilize proteins and cellular structures, as well as redox metabolism to scavenge excess ROS and restore cellular redox balance (You and Chan, 2015). Plants grown in soil supplemented with seaweed accumulate higher levels of proline. It is well known that high proline accumulation is linked to a higher tolerance to stress in the environment (Mansori et al., 2016).

Similarly, an increase in lipid peroxidation under stress conditions is due to the generation of free radicals that distort the membrane architecture, causing oxidative damage (Nada et al., 2007). Due to the relatively higher availability of ion metals in plants irrigated by treated algae, the requirement for antioxidants was low and hence the induction of antioxidants was also lower compared to plants irrigated by untreated algae. The study suggests that plants growing in treated algae irrigated areas have potentially developed a defense strategy to combat environmental stress due to plant hormones, which help to support plant growth under nutrient-stressed conditions and to recover plants after damage (EI Shoubaky and Salem, 2016). 


\section{Antioxidant activity}

Antioxidant enzymes are the first protection mechanism against environmental stress conditions. Plant cells have several response mechanisms against ROS production (Saeed $\boldsymbol{e t}$ al., 2020). The present results revealed a significant decrease in the activities of CAT and SOD in the untreated plants. At the same time, treatment of wheat plants by the application of marine algae, especially $H$. opuntia, increases the activity of antioxidant enzymes which are involved in the scavenging of active oxygen species (Mohy El-Din 2015). The enzyme activities could be attributed to the presence of antioxidant and osmoprotectant components, such as proline, in the investigated marine algal compounds.

Seaweeds have recently been extensively studied for their potential as natural antioxidants (Ozyigit et al., 2016). Similarly, when compared to the control, wheat plants treated with seaweed had significantly higher levels of antioxidant activity. In response to Caulerpa racemosa and Saragasum aquifolium, especially genotype Gemiza171, the highest antioxidant activity was detected. Antioxidants protect plants by maintaining the balance between the synthesis of free radicals and their detoxification, where the accumulation of some ion metals induces oxidative stress because they are involved in several different types of ROS-generating mechanisms. Singh and Agrawal (2010) reported that the antioxidative enzyme; peroxidase showed an increment in its activity in plants grown under the application of seaweed as compared to control ones. Peroxidases play a significant role in defense against oxidative stress (Ozyigit $\boldsymbol{e t}$ al., 2016) and are suggested to be indicators of metal toxicity accumulation (Ghori et al., 2019). An increase in peroxidase activity under environmental stress has also been reported in palak spinach grown at different application rates of seaweed $(\mathbf{X u}$ and Leskovar, 2015).

\section{Conclusion}

In conclusion, the application of some macroalgae, namely Halimeda opuntia, Sargassum aquifolium, Actinotrichia fragilis, Caulerpa racemosa, and Cystoseira myrica on wheat plants influenced nutrient transformation and soil properties, leading to improved wheat growth, yield, and development. The 
improved soil conditions supported greater plant mineral uptake and utilization. The enhanced capacity of treated leaves to scavenge free radicals by elevated antioxidants like peroxidase and catalase and rapid mobilization of stored carbohydrates, proline, and malondialdehyde (MAD) contents during vegetative stages could at least partially explain the beneficial effects of seaweed application on different wheat plants.

\section{Acknowledgement}

The authors would like to express their gratitude to Dr. Aldoushy Mahdy, Associated Professor of Aquatic Ecology, Faculty of Science at Al-Azhar University, who helped us in the collection and identification of the algae and assisted us with manuscript revision.

\section{References}

Abbott, L. K.; Macdonald, L. M.; Wong, M. T. F.; Webb, M. J.; Jenkins, S. N. and Farrell, M. (2018). Potential roles of biological amendments for profitable grain production - A review. In Agriculture, Ecosystems and Environment, $256: \quad 34-50 . \quad$ Elsevier $\quad$ B.V https://doi.org/10.1016/j.agee.2017.12.021.

Aebi, H. (1984). Catalase in vitro. Method Enzymol, 105:121-126.

Aleem, A.A. (1978). A preliminary list of algae from Sierra Leone. Bot. Mar, 21: 397-399.

Al-Shakankery, M; Hamouda, A. and Ammar, M. (2014). The promotive effect of different concentration of marine algae as biofertilizers on growth and yield of maize plants. J.Chem. Biol. Phys.Sci., 4(4): 32013211.

Anjum, S.A.; Wang, L.; Farooq, M.; Xue, L. and Ali, S. (2011). Fulvic Acid Application Improves 508 the Maize Performance under Well-watered and Drought Conditions. J. Agron. Crop 509 Sci. 197, 409-417. doi:10.1111/j.1439-037X.2011.00483.x. 
Bakrudeen, A.; Adel, M.; Talati, A.; Kumar, M. S.; Abdulrahim, K. and Abdulhameed, M. M. (2017). Seaweed Polysaccharides and Their Production and Applications. In Seaweed Polysaccharides: Isolation, Biological and Biomedical Applications 369-382. Elsevier. https://doi.org/10.1016/B978-0-12-809816-5.00020-7.

Basak, M.; Sharma, M. and Chakraborty, U. (2001). Biochemical responses of Camellia sinensis (L.) O. Kuntze to heavy metal stress.J. Environ. Biol., 22: 37-41.

Bates, L.S.; Wladren, P.R. and Tear, D.T. (1973). Rapid determination of free proline for water-stress studies. Plant Soil. 39:205-207.

Chiaiese, P.; Corrado, G.; Colla, G.; Kyriacou, M.C. and Rouphae, Y. (2018). Renewable Sources of Plant Biostimulation: Microalgae as a Sustainable Means to Improve Crop Performance. Front. Plant Sci., 9: 1-6.

Cluzet, S.; Torregrosa, C.; Jacquet, C.; Lafitte, C.; Fournier, J.; Mercier, L.; Salamagne, S.; Briand, X.; Esquerre-Tugaye, M.-T.and Dumas, B. (2004). Gene expression profiling and protection of Medicagotruncatula against a fungal infection in response to an elicitor from green algae Ulva spp. Plant, Cell and Environment, 27(7), 917-928. https://doi.org/10.1111/j.1365-3040.2004.01197.x.

Coppejans, E. andBeeckman, T. (1990). Caulerpa (Chlorophyta, Caulerpales) from the Kenyan coast. Nova Hed., 50: 111-125.

Davari, M.; Sharma, S.N. and Mirzakhani, M. (2012). Residual influence of organic materials, crop residues, and biofertilizers on performance of succeeding mung bean in an organic rice-based cropping system. Int. J. Recycl. Org. Waste Agric. 1: 1-9. https://doi.org/10.1186/2251-7715-114.

DePascale, S.; Rouphael, Y. and Colla, G. (2017). Plant biostimulants: innovative tool for enhancing plant nutrition in organic farming. Eur. J. Hortic. Sci., 82: 277-285. DOI: 10.17660/eJHS.2017/82.6.2.

El Rabey, H.A.; Al-Malki, A.L. andAbulnaja, K.O. (2016). Proteome analysis of date palm (Phoenix dactylifera L.) under severe drought and salt stress. Int. Journal of Genomics.7840759:1-8. 
El Shoubaky, G.A.E. and Salem, E.A. (2016). Effect of Abiotic Stress on Endogenous Phytohormones Profile in Some Seaweeds. International Journal of Pharmacognosy and Phytochemical Research; 8(1): 124-13.

El-Barody, G. S.; Moussa, M. Y.; Shallan, A. M.; Ali, A. M.; Sabh Z. A. and Shalaby, A. E. (2007). Contribution to the Aroma, Biological Activities, Minerals, Protein, Pigments and Lipid Contents of the Red Alga, Asparagopsis taxiformis (Delie) Trevisan. Journal of Applied Sciences Research 3(12): 1825-1834.

EL-Sheikh, M. A.; Sleim, S. N. and Abou-EInasr, H. S. (2020). The Effect of Seaweed Extracts on Chemical Composition of Tomato Plant (Solanum lycopersicum). Alexandria Science Exchange Journal, 41(6): 523-529. https://doi.org/10.21608/asejaiqjsae.2020.135168.

Fales, F. W. (1951). Assimilation and degradation of carbohydrates by yeast cells Journal of Biological Chemistry, 193: 113-24.

Ganesan, A. R.; Tiwari, U. and Rajauria, G. (2019). Seaweed nutraceuticals and their therapeutic role in disease prevention. In Food Science and Human Wellness, https://doi.org/10.1016/j.fshw.2019.08.001

(8)3:252-263.

García-Poza, S.; Leandro, A.; Cotas, C.; Cotas, J.; Marques, J. C.; Pereira, L. and Gonçalves, A. M. M. (2020). The Evolution Road of Seaweed Aquaculture: Cultivation Technologies and the Industry 4.0. International Journal of Environmental Research and Public Health, 17(18): 6528. https://doi.org/10.3390/ijerph17186528.

Ghori, N. H.; Ghori, T.; Hayat, M. Q.; Imadi, S. R.; Gul, A.; Altay, V. and Ozturk, M. (2019). Heavy metal stress and responses in plants. In International Journal of Environmental Science and Technology 16 (3):1807-1828. Center for Environmental and Energy Research and Studies. https://doi.org/10.1007/s13762-019-02215-8.

Hamed, S. M.; Abd El-Rahman, A. A.; Abdel-Raouf, N. and Ibraheem, I. B. M. (2018). Role of marine macroalgae in plant protection and improvement for sustainable agriculture technology. Beni-Suef University Journal of Basic and Applied Sciences, 7(1): 104-110. https://doi.org/10.1016/j.bjbas.2017.08.002. 
Hashem, H. A.; Mansour, H. A.; El-Khawas, S. A. and Hassanein, R., A. (2019). The potentiality of marine macro-algae as bio-fertilizers to improve the productivity and salt stress tolerance of canola (Brassica $\begin{array}{llll}\text { napus } & \text { L.) } & \text { Agronomy, }\end{array}$ 146.https://doi.org/10.3390/agronomy9030146.

Havir, E.A. and Mellate, N.A. (1987). Biochemical and developmental characterization of multiple forms of catalase in tobacco leaves. Plant Physiol, 84: 450-455.

Heltan, M.M.; Wakibia, J.G.; Kenji, G.M. and Mwasaru, M.A. (2015). Chemical composition of common seaweeds from the Kenya Coast. $J$. Food Res, 4: 28-38.

Kalaivanan C.; Chandrasekaran, M. and Venkatesalu, V. (2012). Effect of seaweed liquid extract of Caulerpa scalpelliformis on growth and biochemical constituents of black gram (Vigna mungo (L.) Hepper). Phykos, 42 (2): 46-53.

Khan, W.; Rayirath, U.P.; Subramanian, S.; Jithesh, M.N.; Rayorath, P.; Hodges, D.M.; Critchley, A.T.; Raigie, J.S.; Norrie, J. and Prithiviraj, B. (2009). Seaweed extracts as biostimulants of plant growth and development. J. Plant Growth Regul., 28(4):386-399.

Korzen, L.; Pulidindi, I.N.; Israel, A.; Abelson, A. and Gedanken, A. (2015). Single step production of bioethanol from the seaweed Ulva rigida using sonication., $R S C A d v$., 5: 16223-16229.

Kosar, F.; Akram, N.A. and Ashraf, M. (2015). Exogenously applied 5aminolevulinic acid modulates some key physiological characteristics and antioxidative defense system in spring wheat (Triticum aestivum L.) seedlings under water stress. South Afric. J. Bot., 96: 71-77.

Kumar, G. and Sahoo, D. (2011). Effect of seaweed liquid extract on growth and yield of Triticum aestivum var. Puas Gold. J. Appl. Phycol., 23(3): 251255.

Kumar, S.; Sehgal, S. K.; Kumar, U.; Prasad, P. V. V.; Joshi, A. K. and Gill, B. S. (2012). Genomic characterization of drought related traits in spring wheat. Euphytica, 186(1): 265-276.doi: 10.1007/s10681-012-0675-3. 
Latique, S.; Chernane, H.; Mansori, M., Kaoua, E. (n.d.) (2013). Seaweed Liquid Fertilizer Effect On Physiological and Biochemical Parameters of Bean Plant (Phaesolus Vulgaris Variety Paulista) Under Hydroponic System. European Scientific Journal, (9) 30: 174-191.

Lichtenthaler, H.K. (1987). Chlorophyll and carotenoids: pigments of photosynthetic biomembranes. Methods Enzymol., 148:331-382.

Madhava, R.K.V. and Sresty, T.V.S. (2000). Antioxidative parameters in the seedlings of pigeon pea (Cajanus Cajan L. Millspaugh) in response to $\mathrm{Zn}$ and Ni stresses. Plant Sci., 157:113-128.

Maehly, A.C. and Chance, B. (1954). The assay of catalase and peroxidase. In: Glick, D, editor. Methods in biochemistry analysis, New York: Interscience Publishers; (1): 357-424.

Mancuso, S., Azzarello, E., Mugnai, S., Briand, X. (2006). Marine bioactive substances (IPA extract) improve ion fluxes and water stress tolerance in potted Vitis vinifera plants. AdvHortic Sci., 20:156-161.

Mansori, M.; Chernane, H.; Latique, S.; Benaliat, A.; Hsissou, D. and El Kaoua, M. (2016). Effect of seaweed extract (Ulva rigida) on the water deficit tolerance of Salvia officinalis L. J Appl Phycol, 28:1363-1370.

Mirparsa, T.; Ganjali, H.R. and Dahmardeh, M. (2016). The effect of biofertilizers on yield and yield components of sunflower oil seed and nut. Int. J. Agric. Biosci., 5: 46-49.

Mohy El-Din, S.M. (2015). Utilization of seaweed extracts as bio-fertilizers to stimulate the growth of wheat seedlings, Egypt. J. Exp. Biol. (Bot.), 11(1): 31-39.

Muhammad, S.; Anjum, A.S.; Kasana, M.I. and Randhawa, M.A. (2013). Impact of organic fertilizer, humic acid and sea weed extract on wheat production in Pothowar region of Pakistan. Pak. J. Agri. Sci., 50: 677681.

Nabti, E.; Jha, B. and Hartmann, A. (2017). Impact of seaweeds on agricultural crop production as biofertilizer. Int. J.Environ. Sci. Technol., (14): 11191134. 
Nada, E.; Ben, A. E.; Ferjani, A.; Rhouma, A. E.; Ae, A.; RwinaBechir, B.; Mezghani, A. E.; Ae, I. and Makki, B. (2007). Cadmium-induced growth inhibition and alteration of biochemical parameters in almond seedlings grown in solution culture. Springer. Acta Physiol Plant., 29:5762. DOI 10.1007/s11738-006-0009-y(3)https://doi.org/10.1007/s11738006-0009-y.

Nassar, R.M.A.; Shanan, N.T. and Reda, F.M. (2016). Active yeast extract counteracts the harmful effects of salinity stress on the growth of leucaena plant. Scientia Hortic., 201: 61-67.

Nawar, D.A.S. and Ibraheim, S.K.A. (2014). Effect of Algae Extract and nitrogen fertilizer rates on growth and productivity of peas. Middle East $J$. Agric. Res., 3 (4): 1232-1241.

Nazi, H.; Akrami, N.A. and Ashraf, M. (2016). Impact of ascorbic acid on growth and some physiological attributes of cucumber (Cucumissativus) plants under water-deficit condition. Pakistan Journal of Botany, (48): 877-883.

Ozyigit, II; Filiz, E.; Vatansever, R.; Kurtoglu, K.Y.; Koc I, Öztürk, M.X. and Anjum, N.A. (2016). Identification and comparative analysis of $\mathrm{H}_{2} \mathrm{O}_{2}$-scavenging enzymes (ascorbate peroxidase and glutathione peroxidase) in selected plants employing bioinformatics approaches. Front Plant Sci., 7:301.

Pise, N.M. and Sabale A.B. (2010). Effect of Seaweed Concentrates On The Growth and Biochemical Constituents of Trigonella Foenum-Graecum L. J Phytol.,2(4) 50-56.

Pramanick, B.; Brahmachari, K.; Mahapatra, B. S.; Ghosh, A.; Ghosh, D. and Kar, S. (2017). Growth, yield and quality improvement of potato tubers through the application of seaweed sap derived from the marine alga Kappaphycus alvarezii. Journal of Applied Phycology, 29(6): 32533260. https://doi.org/10.1007/s10811-017-1189-0.

Salah El Din, R. A.; Elbakry, A. A.; Ghazi, S. M. and Abdel Hamid, O. M. (2008). Effect of seaweed extract on the growth and yield of faba bean (VICIA FABA L.). Egyptian Journal of Phycology, 9(1), 25-38. https://doi.org/10.21608/EGYJS.2008.114808. 
Rathore, S. S.; Chaudhary, D. R.; Boricha, G. N.; Ghosh, A.; Bhatt, B. P.; Zodape, S. T. and Patolia, J. S. (2009). Effect of seaweed extract on the growth, yield and nutrient uptake of soybean (Glycine max) under rainfed conditions. South African Journal of Botany, 75(2): 351-355. https://doi.org/10.1016/j.sajb.2008.10.009.

Rouphael, Y.; Giordano, M.; Cardarelli, M.; Cozzolino, E.; Mori, M.; Kyriacou, M., Bonini, P. and Colla, G. (2018). Plant- and SeaweedBased Extracts Increase Yield but Differentially Modulate Nutritional Quality of Greenhouse Spinach through Biostimulant Action. Agronomy, 8(7): 126. https://doi.org/10.3390/agronomy8070126.

Saeed, A.; Abotaleb, S.; Alam, N.; ELMehalawy, A. and Gheda, S. (2020). In vitro assessment of antimicrobial, antioxidant and anticancer activities of some marine macroalgae. Egyptian Journal of Botany. 60(1): 81-96. http://dx.doi.org/10.21608/EJBO.2019.11363.1303.

Safinaz, A. F. and Ragaa, A. H. (2013). Effect of some red marine algae as biofertilizer on growth of maize (Zea mays L.) plants, Intern. Food Res. J., 20(4): 1629-1632.

Schlegel, H. G. (1956). Die Verwertung organischer Säuren durch Chlorella im Licht. Planta, 47(5): 510-526. https://doi.org/10.1007/BF01935418.

Silva-Ortega C.O; Ochoa-Alfaro, A.E.; Reyes-Agüerob, J.A.; AguadoSantacruz, G.A. and Jimenez-Bremont, J.F. (2008). Salt stress increases the expression of P5CS gene and induces proline accumulation in cactus pear. Plant Physiology and Biochemistry 46:82-92.

Singh, R.P. and Agrawal, M. (2010). Effect of different sewage sludge applications on growth and yield of Vigna radiata L. field crop: Metal uptake by plant. Ecol. Eng., 36: 969-972.

Sivasankari, S.; Venkatesalu, V.; Anantharaj, M. and Chandrasekaran, M., (2006).Effect of seaweed extracts on the growth and biochemical constituents of Vigna sinensis. Bioresour. Technol. 97: 1745-1751.

Tarakhovskaya, E. R.; Maslov, Yu.I. and Shishova M. F. (2007). Phytohormones in Algae. ISSN 1021-4437, Russian J. of Plant Physiology, 54 (2): 163-170. 
Thorsen, M.K.; Woodward, S. and McKenzi, B.M. (2010). Kelpaffects rooting and plant vigour in crops and native plants from arable grassland in the Outer Herbides, Scotland. J. Coast. Conserv, 14(3): 239-247.

Tuhy, Ł., Samoraj, M., Baśladyńska, S., Chojnacka, K. (2015). New micronutrient fertilizer biocomponents based on seaweed biomass. Polish Journal of Environmental Studies, 24(5):2213-2221. https://doi.org/10.15244/pjoes/39552.

Xie, X.; He, Z.; Chen, N.; Tang, Z.; Wang Q. and Cai, Y. (2019). The roles of environmental factors in regulation of oxidative stress in plant. BioMed Research Int, 2019:21-27.

Xu, C. and Leskovar, D. I. (2015). Effects of A. nodosum seaweed extracts on spinach growth, physiology and nutrition value under drought stress. Scientia Horticulturae., 183: 39-47. https://doi.org/10.1016/j.scienta.2014.12.004.

Yakhin, O. I.; Lubyanov, A. A.; Yakhin, I. A. and Brown, P. H. (2017). Biostimulants in plant science: a global perspective. Front. Plant Sci., 7:2049. DOI: 10.3389/fpls.2016.02049.

You, J. and Chan, Z. (2015). ROS regulation during abiotic stress responses in crop plants. Front. Plant Sci., 6: 1092

Zhang, X. and Ervin E.H. (2008). Impact of Seaweed Extract-Based Cytokinins and Zeatin Riboside on Creeping Bentgrass Heat Tolerance, Virginia Polytechnic Institute and State Univ Crop Sci., 48:364-370.

Zhang, X. and Ervin, E. H. (2004). Cytokinin containing Seaweed and Humic Acid Extracts Associated with Creeping Bentgrass Leaf Cytokinins and Drought Resistance. Crop Science, 44(5): 1737-1745. https://doi.org/10.2135/cropsci2004.1737. 


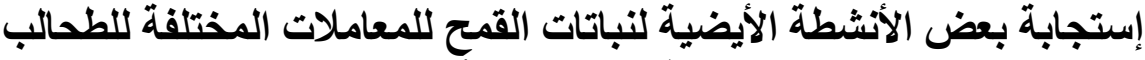

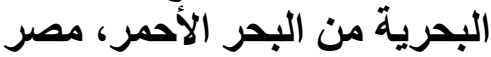

محمد طلعت'، عبدالكريم سيد حسين محمد'، محمد زين العابدين نصار '، نـاجح فتحى أبوالدهب'

$$
\begin{aligned}
& \text { اـ قسم / لنبات ،كلية العلوم ،جامعة الأزهر، فرع أسبيوط، مصر. }
\end{aligned}
$$

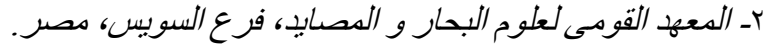

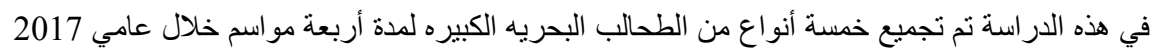

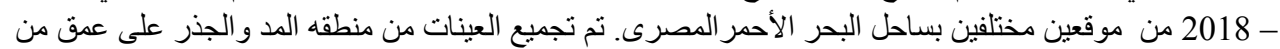
2-1 متر ا بإستخدام طريقه الغطس الحر (السنوركل).

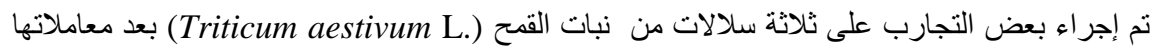

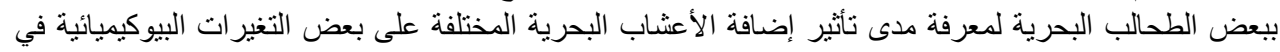
هذه النباتات. تمت معاملة سلالات القمح بخمسة أنواع مختلفة من معالجات الأعشاب البحرية وهى: Halimeda و Saragasum aquifolium, Cystoseira myrica, Caulerpa racemosa sopuntia .Actinotrichia fragilis

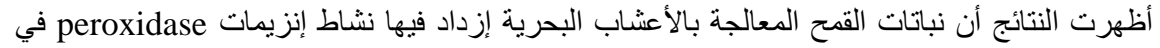

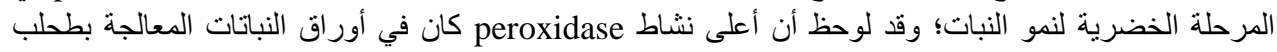

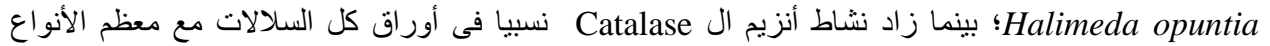
الطحلبية المختلفة؛ وقد سجلت الزيادة القصوى لهذا الإنزيم عند المعالجة بأنواع Halimeda opuntia و Actinotrichia fragilis وSaragasum aquifolium أوضحت النتائج أيضا أن مستوى الكربو هيدرات الكلية والأنشطة الأيضية الأخرى مثل محتوى البرولين

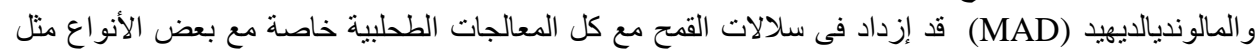
Aaulerpa racemosa و Actinotrichia fragilis Sargassum aquifolium في محتوى المالونالدهيد (MAD) في الأوراق المعالجة بطحلب Halimeda opuntia .

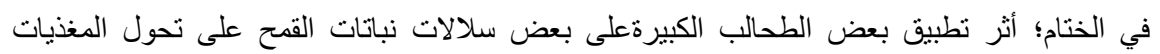

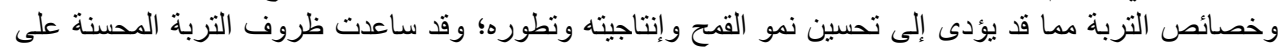

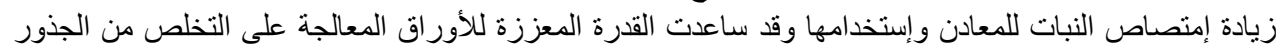

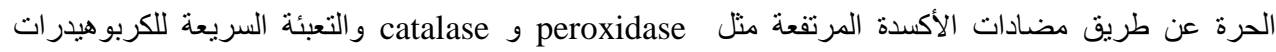
المخزنة والبرولين ومحتوى المالونالدهيد (MAD) خلال المر احل الخضرية الفية يمكن أن تفسر جزئيًا على الأقل الآثار المفيدة لتطبيق الأعثاب البحرية على نباتئات القمح المختلفة. 